Article

\title{
Scenic Railway Mapping: An Analysis of Spatial Patterns in France Based on Historical GIS
}

\author{
Guiye Lin ${ }^{1}$, Luoning Xiang ${ }^{2}$ and Kun Sang ${ }^{3, *(D)}$ \\ 1 Department of Civil, Environmental and Architectural Engineering, University of Padua, 35131 Padova, Italy; \\ guiye.lin@studenti.unipd.it \\ 2 College of Horticulture and Landscape Architecture, Zhongkai University of Agriculture and Engineering, \\ Guangzhou 510225, China; luoningxiang@foxmail.com \\ 3 Department of Advertising, Xiamen University Malaysia, Sepang 43900, Malaysia \\ * Correspondence: kun.sang@xmu.edu.my
}

check for updates

Citation: Lin, G.; Xiang, L.; Sang, K. Scenic Railway Mapping: An Analysis of Spatial Patterns in France Based on Historical GIS. ISPRS Int. J. Geo-Inf. 2022, 11, 99. https:// doi.org/10.3390/ijgi11020099

Academic Editors: Andreas Georgopoulos and Wolfgang Kainz

Received: 25 November 2021

Accepted: 30 January 2022

Published: 31 January 2022

Publisher's Note: MDPI stays neutral with regard to jurisdictional claims in published maps and institutional affiliations.

Copyright: (C) 2022 by the authors. Licensee MDPI, Basel, Switzerland. This article is an open access article distributed under the terms and conditions of the Creative Commons Attribution (CC BY) license (https:// creativecommons.org/licenses/by/ $4.0 /)$

\begin{abstract}
Scenic railway refers to the trains that operate for tourism purposes, which are mainly maintained for facilitating leisure activities, scenic tours, and heritage experiences. As both an extension of railway heritage and an important redevelopment method, this concept is meaningful for the touristic development of historical railways but has received less attention in academia. To understand the tourism and landscape values of scenic railways from a geo-historical perspective and discuss the recent techniques and methods for railway tourism, this article first introduces the relationship between railway and landscape and the concept of scenic railway in French literature. Secondly, it analyzes the current distribution of French scenic railways based on geographic information system (GIS) tools. Through georeferencing, mapping, data relating and joining, calculating, and classifying, different groups of scenic railways are systemized and published online. Following statistical treatment, the pattern of distribution of scenic railways in comparison with the standard-gauge railway system in France is revealed. Based on the discussions on scenic railways, further study should focus more on the landscape evaluation of scenic railways and its integration with other spatial technologies for deeper geo-analysis. Moreover, the research results can serve as a reference for the development of relative railway heritage and tourist activities.
\end{abstract}

Keywords: scenic railway; France; railway heritage; GIS

\section{Introduction}

Railway, as a product of modern technologies, was created in the early 19th century in the United Kingdom (UK). Its invention has resulted in totally new experiences for visitors. Meanwhile, railway has also strengthened connections between remote places, changed the ways of living and entertaining, and played a crucial role in social-economic growth [1]. Having been developed for nearly 200 years, the train is currently known as a basic element of the land transport system and regarded as a green method of moving due to its characteristics of low price, large capacity, limited environmental emission, and lower dependence on climatic conditions. In recent years, along with other industrial heritages, historical railways have gained wide attention in academia. Since the inscription of several historical railways by the United Nations Educational, Scientific and Cultural Organization (UNESCO), such as the famous case of the Rhaetian Railway between Italy and Switzerland, the significance of railway heritage protection has been clarified, which includes the establishment of a criterion for evaluating railway heritage from the perspectives of its innovative, scientific, technological, and socioeconomic influences throughout history [2]. However, there are still many old railways, including narrow-gauge railways, mine railways, forest railways, and urban trams, which have been almost abandoned and neglected in both urban and suburban areas (e.g., Figure 1). The renewal and protection of these sites and related railway relics confront a series of difficulties, such as conflicts 
with modern urban construction, the high expense of maintenance, the destruction of old railway buildings, complex administrative systems, and inadequate perception of railway heritage [3]. Due to the abovementioned reasons, the existence of many old railways is threatened, and they await an uncertain future.

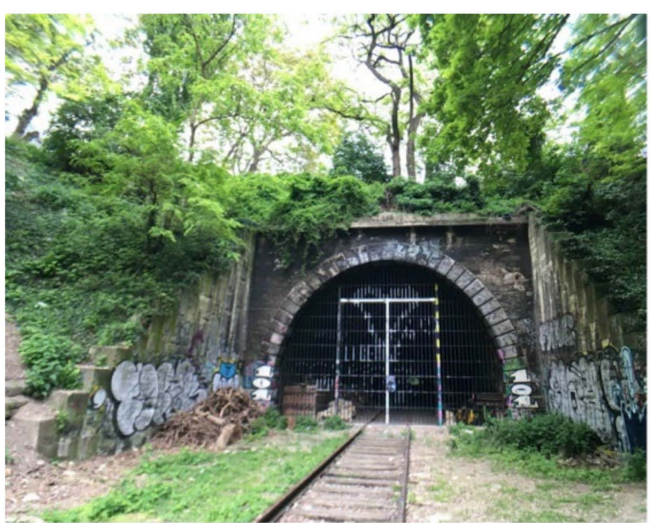

(a)

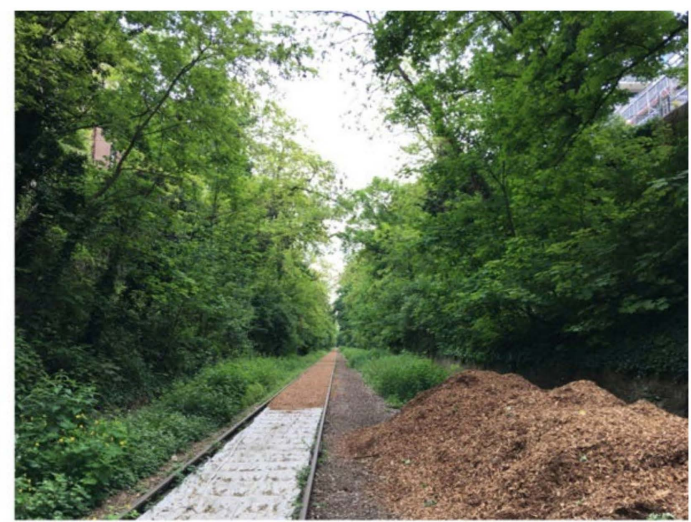

(b)

Figure 1. (a) Abandoned railway in the center of Paris (La Petite Ceinture); (b) reconstruction of the old railway.

In facing these crises and challenges, exploring relevant experiences and introducing recent techniques and methods are of great importance for railway tourism and heritage protection [4]. Some research has been conducted related to the redevelopment of railway heritage in the UK, the United States (USA), and other developed countries, where more practical measurements and regulations have been produced. For example, the book Protecting Railway Heritage first summarizes the theories and practices for the protection of railway heritage in the UK [5]. The European Federation of Museum \& Tourist Railways (FEDECRAIL), in 2003, defined railway heritage as "historic railways, working railways, urban trams, railway museums, tourist railways, and heritage trains" [6]. Not only should all the related buildings or infrastructure be involved in railway protection but also the technical skills of railway construction and management are important relics of railway history. Operating railways via traditional procedures, i.e., presenting and reusing them for the public, is considered crucial for maintaining railway culture.

Among the developed countries, France has rich achievements in railway construction and heritage studies. The first railway in France was opened in 1827. Since then, the railway network had been consistently expanded in France. In 1971, the National Railway Museum (Cité du Train) was established in Mulhouse, a city in Eastern France. In 1977, the reconstruction of the Orsay Railway Station, as a national museum, successfully attracted the wide attention of the public. In 1987, the "Association pour l'Histoire des Chemins de Fer (AHICF)" was constituted, which aimed to save railway documents, organize research funds, and construct a scientific database for all French historical railways. Thus, multidisciplinary methods combining historical geography, urban planning, heritage conservation, and landscape architecture were introduced into railway heritage research. In the 1980s, during the national survey of industrial heritage, 3194 industrial sites were registered, of which $26 \%$ belonged to the railway sector [7]. In 1990, a journal of the history of railway, Revue d'histoire des chemins de fer, paid more attention to the topic of railway heritage and landscape started circulating [8]. Up to 2017, France owned a railway network of 100.2 billion $\mathrm{km}$. In 2019, the volume of railway passengers continues to expand [9], and the current railways in operation have a total length of about $28,183 \mathrm{~km}$, which successfully ensures that the remote countryside is more accessible than in the past. As seen in Figure 2, the expansion of French railway can be classified into three phases: 1840-1860, for linking major cities to Paris; 1860-1900, providing direct connections among all the prefectures; and 1900-1930, constructing the local railways. Thus, the density of the railway network 
is higher in the north than the south, and Île-de-France, Rhône-Alpes, and Centre Val de Loire are the three regions with the longest railway expansions [10].

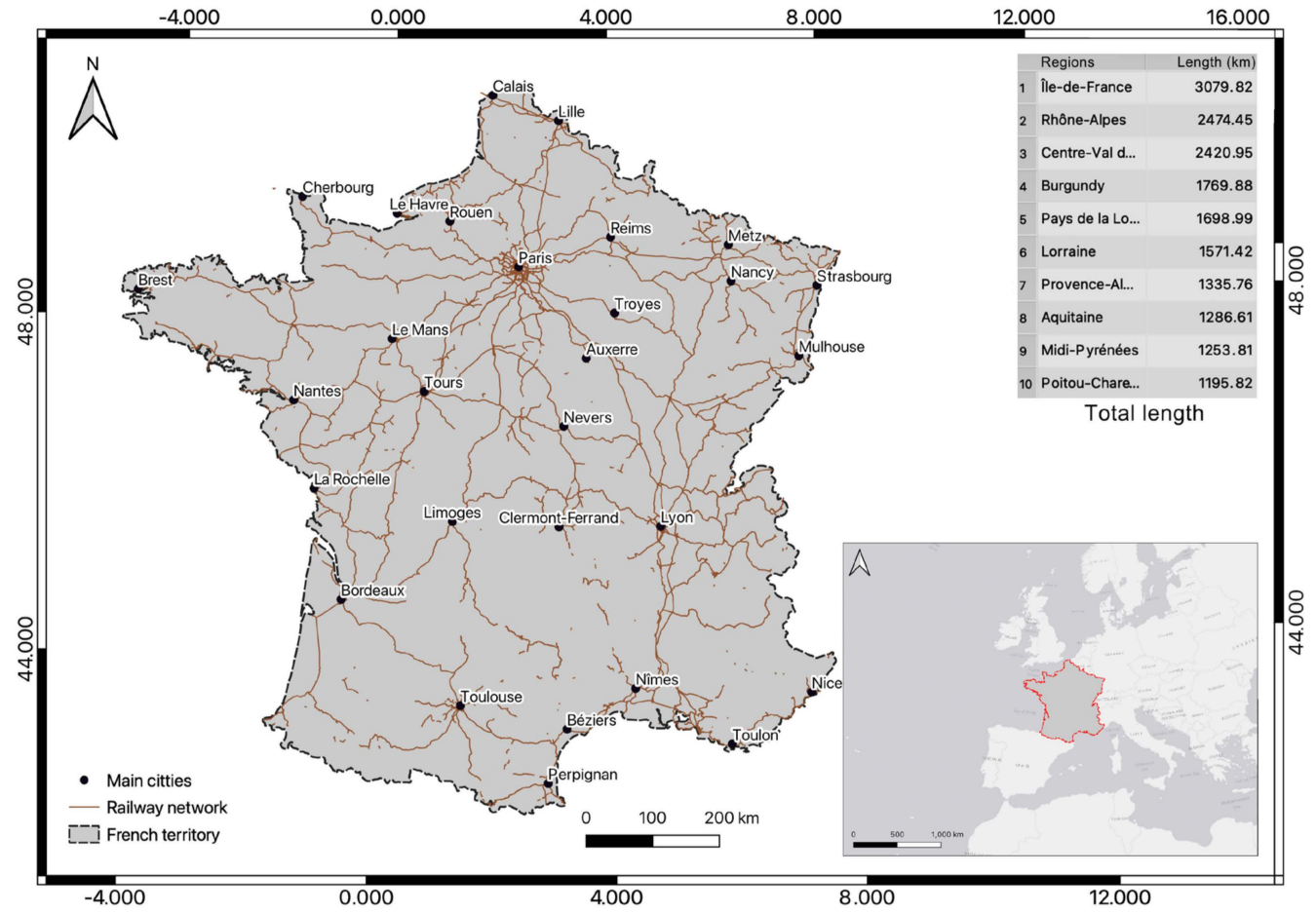

Figure 2. Railway system in France.

\section{Literature Review}

\subsection{Railway and Landscape}

The relationship between railway and landscape has been examined by previous scholars. Railway is a tool used to perceive landscapes, a creator and reformer of landscape, as well as an aesthetic object for landscape contemplation. During the industrial revolution, the train, as a large industrial machine, was considered to be in conflict with picturesque and natural landscapes. In some modern literature, train experiences were described as boring, unhappy, and even fearful by visitors [11]. With the development of railway tourism, its negative image has gradually been transformed, and the attractiveness of railway travel has also been acknowledged and increased, reflected from the landscape paintings in the 20th century, in which railway elements widely emerged and were emphasized [12]. Landscape quality becomes significant for railway heritage and tourism. For example, in the famous cases of Darjeeling Railway and Semmering Railway in the World Heritage List (WHL), railway is understood as a force that helped to transfigure land and railway together as a landscape, attracting more and more visitors $[13,14]$. Besides, more studies were focused on the landscape quality along railways. For example, railways are regarded as resilient infrastructure to steer and root modernization processes on landscape [15], railway elements are used as some visible conceptual landmarks and a link between historical events and public memories in landscape design [16], and some historic railways are reconstructed a cultural route to connect touristic activities and preserve the integrity of the heritage within a landscape setting [17].

The "scenic railway" has thus been discussed in French literature since the 1990s, which is concerned more with railway and landscape from the perspectives of history, tourism, and heritage protection. French scholars have summarized previous research and creatively proposed a comprehensive concept that is defined as the railways used for leisure, entertainment, sightseeing, and heritage experiences, i.e., mainly for the purpose of tourism rather than transportation [18]. The scenic railway originated from two motivations: exploring nature and protecting railway heritage. Its scenic meaning includes the landscape 
observed from the window of a train and related railway facilities themselves along the rail path [19]. They have the common features, such as short driving routes, low speed, distribution along with railway heritage, high scenery quality along the path, specially designed sightseeing cabins, and flexible operating hours determined by the tourism companies. It can be seen that landscape, heritage, and tourism are the three core values of a scenic railway, which are closely connected with each other. In daily life, scenic railway is understood as a railway with high landscape quality along the rail, usually classified into the category of greenway, which emphasizes the green infrastructure with multifunction of ecology, recreation, economy, and culture in urban planning, whose construction is usually based upon heritage reserves, national parks, waterways, etc. [20,21]. However, the regeneration strategies of renovating abandoned railways as greenway results in railways losing their original functions, and the rail or locomotive is only retained as a symbol of industrial memory. By contrast, scenic railway is closely related to tourism and heritage protection, and the old railways adapted as scenic railways could continuously maintain their vitality.

\subsection{Railway and Spatial Technologies}

In the practices of heritage protection, spatial technologies have brought substantial changes in the process of documentation, investigation, monitoring, evaluation, restoration, planning, redevelopment, and touristic reuse of both cultural and natural heritage [22,23]. Geographic information system (GIS), remote sensing (RS), and global positioning system (GPS) are the most important spatial technologies, among which GIS has become increasingly more closely connected with history and heritage [24]. Considered as a digital container and spatial toolbox for the documenting of comprehensive information of historical relics, it use is associated with multiple advantages in heritage studies and projects, including facilitating and simultaneously processing a large amount of data, using a geodatabase for effective data management, and interpreting and sharing information through the Internet for multi-users [25]. In 1992, GIS was firstly adopted in the heritage plan of UNESCO for Angkor in Cambodia (an important archaeological site in Southeast Asia). A heritage database was also built for coordinating related administrative departments and avoiding the destruction of heritage sites [26]. Currently, GIS is also associated with territorial laser scanning (TLS); building information modeling (BIM); and other new techniques for mapping, digitalizing, and modeling heritage [27].

The GIS approach was also applied to the study of railway and its history. For example, Siebert discussed the methodology for the geometric representation of railway segments and junction stations, which laid the foundation for mapping historical railway systems in a GIS environment [28]. Considering a national scale, in Britain, the expansion of the railway system during the nineteenth and twentieth centuries and its impact on population growth was studied by GIS [29]. Then, on a continental scale, the evolution pattern of railway network in Europe was analyzed to reveal the large-scale demographic changes [30] and explain the relationship between urbanization and railway [31,32]. A geospatial database of historical railways was also created for mapping the overall railway system and its changes in Europe [33]. Studies on the development of French railway system using the GIS approach have been conducted. In the north of France, railway growth was found to have facilitated economic dynamism, and in the south, it had mainly led to increased agricultural productivity and growth [34]. Using GIS, the relationship between railway accessibility and population changes in France was also examined [35]. Furthermore, more recent research also points to the value of bringing together individualized landscape perceptions and evaluations with methods of geo-information, such as in GIS analysis and thematic cartography [36,37]. However, in these studies, railway is simply considered as a social factor influencing the urban and economic development and not as an object of heritage to protect, and scenic railways were not mapped and analyzed in these projects.

As a part of the French railway system, the number of scenic railways has increased steadily in the recent 150 years due to an emphasis on the reuse of historical railways in 
France. They continuously provide huge economic and social benefits to the country [38]. According to the statistics published by the Union des Exploitants de Chemins de Fer Touristiques et de Musées (UNECTO) [39], the number of scenic railways increased from 16 in 1982 to 52 in 2006. Currently, there are 81 scenic railways on French continental territory (the overseas territory is not included), covering nearly $1200 \mathrm{~km}$, spreading throughout the whole territory. Every year, they generate more than EUR 50 million of revenue and activate an increasing number of jobs for the tourism market. Analyzing the distribution pattern of the scenic railway is meant to allow understanding of the railway density in each region and its contributions to economic investments. It can also provide a social-economic index for application in tourism. Based on the concept of scenic railway, updating railway heritage and developing railway tourism can not only enhance the competitiveness of railway but also meet the nostalgia for the steam age and the needs to be close to the natural environment $[40,41]$.

In summary, the combination of GIS technology with scenic railway, discussed in this paper, is novel and can act as a reference for the research of railway heritage for other countries. After a brief introduction of the relationship between landscape and railway, in the Literature Review section, this paper discusses "scenic railway" as a concept in heritage protection and tourism, compared with other similar concepts. Based on previous studies [42], in the Materials and Methods section, GIS and its spatial tools are also introduced in analysis of the spatial distribution of scenic railway and compared with the situation of other normal railway systems in France. After classification of these railways, the statistical analyses of scenic railway are conducted, focusing on their regional differences. As a result, ways of sharing the GIS data created for scenic railways are also discussed. In conclusion, further possibilities of introducing other methods to study the railways are also introduced and discussed.

\section{Materials and Methods}

After searching for each scenic railway through the official website of UNECTO, the detailed records of the 81 railways, including their locations, length, gauge, and the number of visitors, were collected as a list of scenic railways in an Excel table, and a map of the distribution of scenic railways was from previous research [43].

Traditionally, the framework of GIS contains data acquisition; data analysis with GIS software; and outputting data in the form of maps with charts, graphs, and visualizations. This paper follows the GIS methodology, using the historical GIS method inspired by some previous research $[44,45]$. The detailed workflow in this paper includes georeferencing, remapping, data relating and joining, density calculating, classifying, and outputting data online. All steps were fulfilled with the help of the open and free application Quantum GIS (QGIS 3.16), which is a powerful software for creating, editing, visualizing, and publishing geospatial information.

\subsection{Georeferencing}

To systemize and relocate all the railways, the collected reference map needs to be georeferenced to allow obtaining geo-information from it. Thus, georeference is a process used to align the reference map to a known map projection or coordinate system. There are five points selected as reference points, and the transformation type is "polynomial 1" while the resampling method is "nearest neighbor". The target projected map system is “WGS 84-UTM zone 31N" (The World Geodetic System 84-Universal Transverse Mercator projection). As a result, all the locations of scenic railways can be marked in a new map for further analysis. As is shown in Figure 3, the georeferencing has a low residual number of pixels—an average value of 1.07 . 


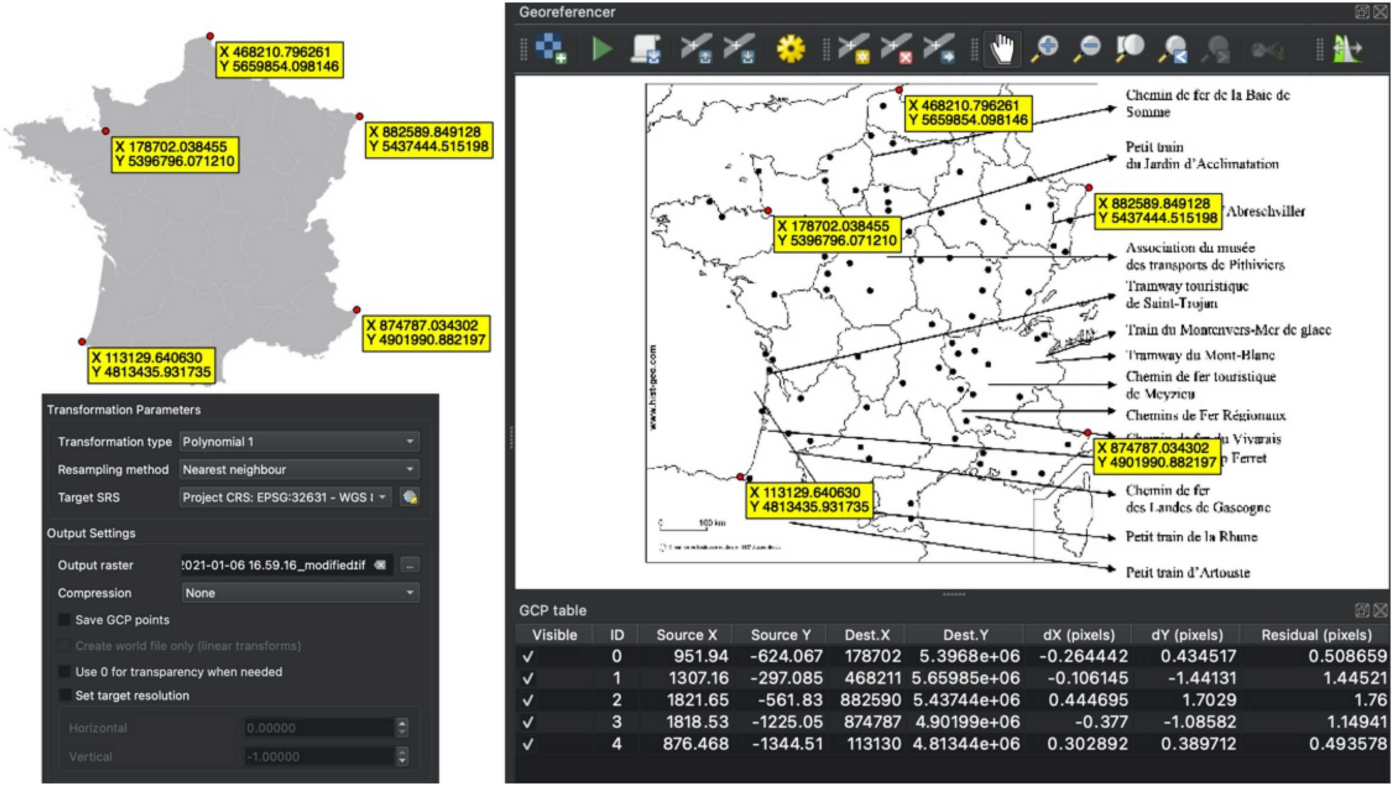

Figure 3. Georeferencing maps.

\subsection{Remapping the Scenic Railways}

After the collection of information on railways, 81 scenic railways were marked on the main territory of France according to the sequence in the built scenic railway list and the georeferenced map output in the last step. The coordinate system of the new layer of scenic railway follows the map projection of WGS 84-UTM zone 31N. Because of the limited length of scenic railway compared to the normal railways, they are represented as points on the map (Figure 4).

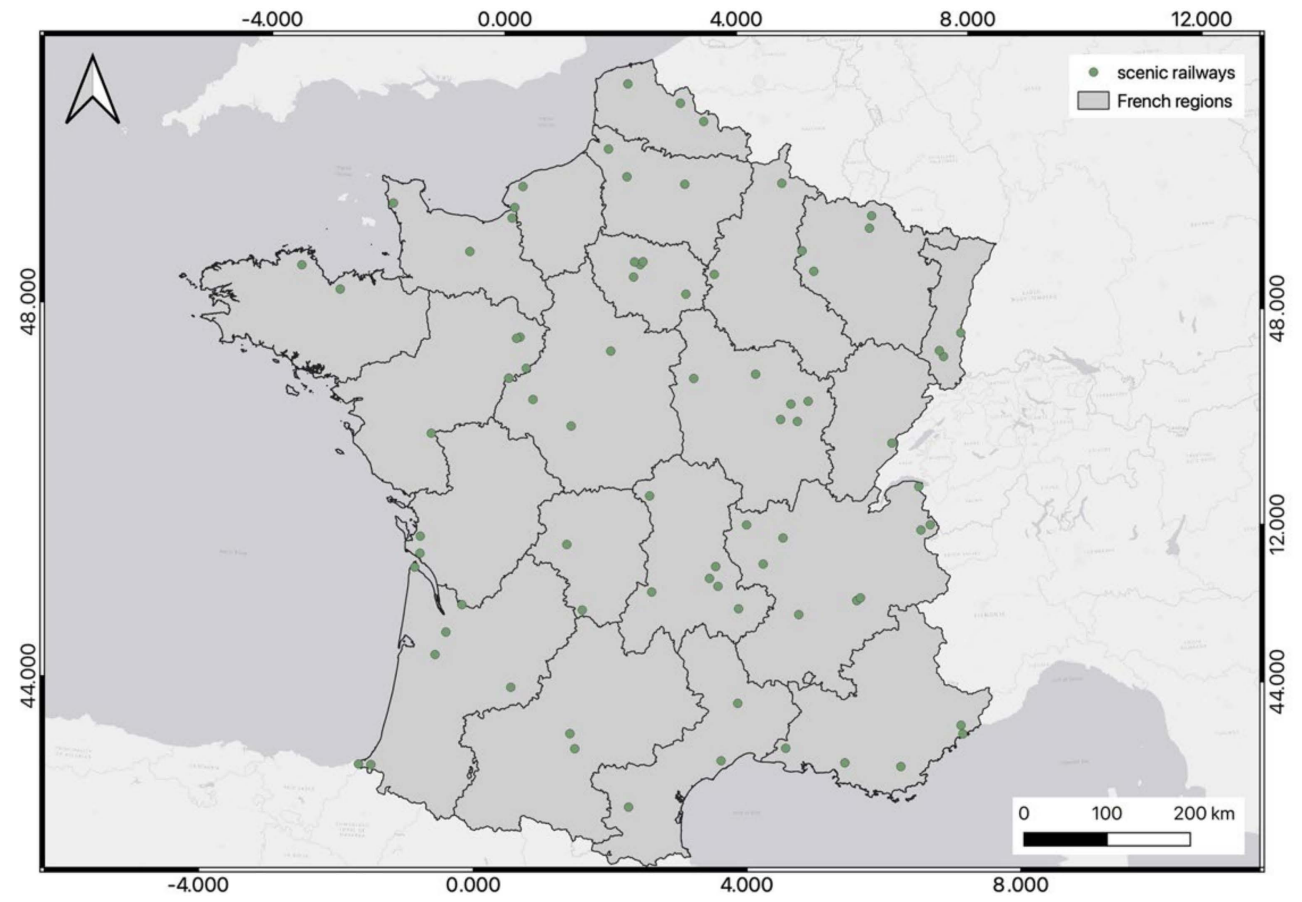

Figure 4. Remapping the points of scenic railways.

\subsection{Relating and Spatial Joining}

The list of scenic railways was imported into GIS as an attribute table connected with the point layer. The Excel table was first transformed as an attribute table by the QGIS tool 
"add delimited text layer". Then, the table was joined with the scenic railway layers created in the previous step, which are connected by their common ID number as the primary key, and the information (including the name of railway, location (city), gauge, length, visitors, and railway type from the list) is inputted as joined fields to the point data layer. Then, to add the location of railway in each region, the spatial join tool was used, namely the "join attributes by location". The scenic railway layer and the French region layer intersected with each other. If a railway is located within a certain region, the name of the region will be added to the attribute table of the scenic railway layer. Thus, the join type of these two layers is the "one-to-many" relationship, namely, a region that can contain the number of railways, but a scenic railway point can belong to only one region (Figure 5).

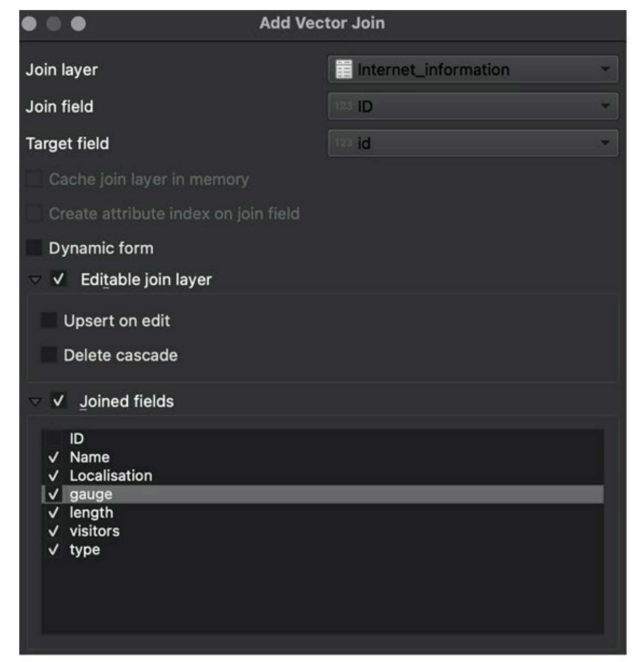

(a)

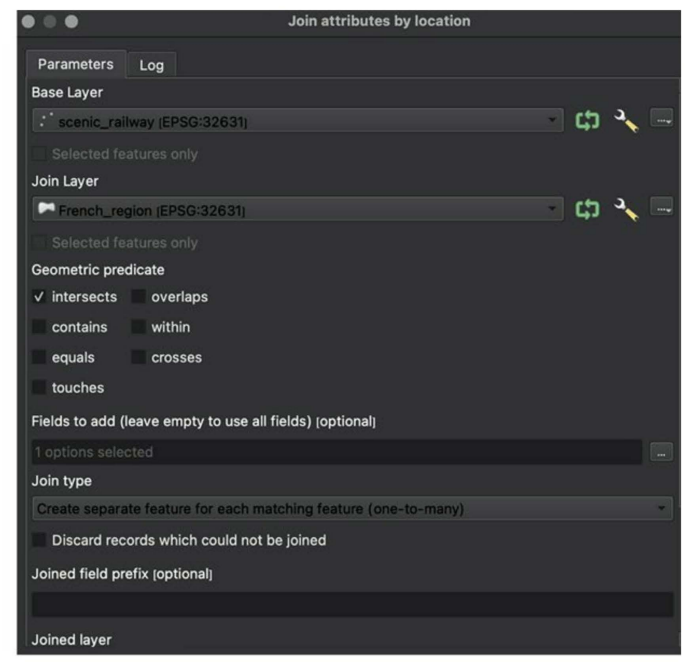

(b)

Figure 5. "Add vector join (a)" and "Join attribute by location (b)" in QGIS.

\subsection{Density Calculation}

Kernel density estimation (KDE) in QGIS, often applied to estimate probability density functions, was then used to estimate the density of scenic railway in France. By the statistical tool, the mean value of kernel density is assigned to every region of France to compare the scenic railway kernel density. Figure 6 reveals that Ile de France, Centre Val de Loire, Auvergne, and Rhône-Alpes are the regions with the highest kernel density of scenic railways.

Due to the different types of data collected (scenic railway as point data and normal railways as line data), the density of normal railway is also calculated based on the railway system of France. Through line density calculation, a magnitude-per-unit area from line features falling within a radius is obtained, and the results show that Nord-Pas-de-Calais, Upper Normandy, Ile de France, and Alsace are the regions with the highest railway density. Basically, the distribution of scenic railways and other railways follows a similar pattern, namely, with a higher density in the north than the south (Figure 6). Limousin, Auvergne, and lower Normandy have a denser distribution of scenic railway but a lower concentration of railway systems, whereas Compagne-Ardenne, Poitou-Charentes, and Provence-Alpes-Côte d'Azur have a higher density of railways but lower distribution of scenic railways. 


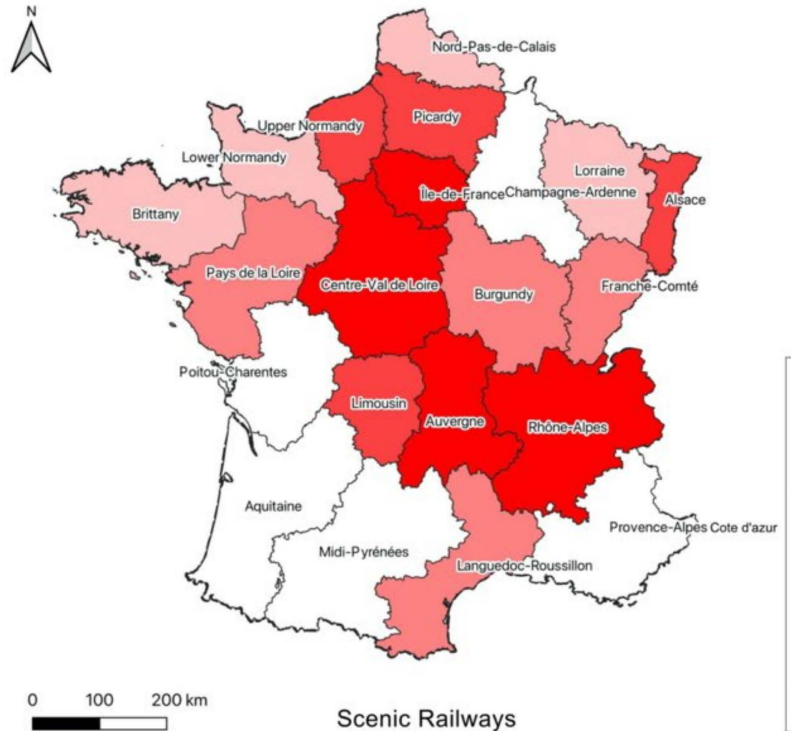

(a)

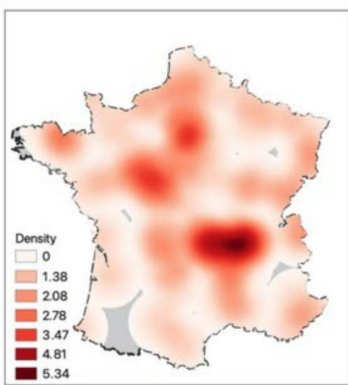

Heatmap of scenic railways

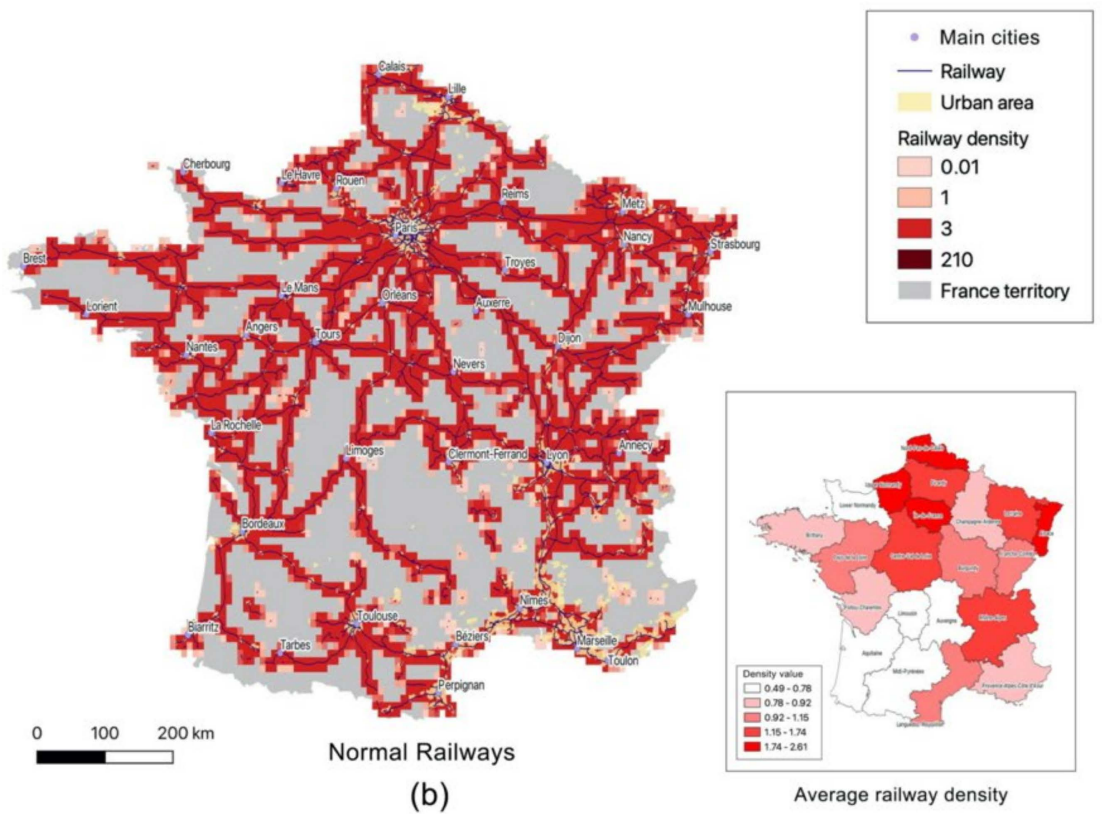

Figure 6. KDE of scenic railway (a); line density of normal railways in France (b).

\subsection{Classification of Scenic Railways}

The management of scenic railways is the result of a joint effort from multiple stakeholders, including various governmental departments, railway companies, private groups, railway associations, railway enthusiasts, and volunteers. At present, according to the evolution of rail technology, economic and tourism needs, and the differences in landscape, French scholars have divided scenic railways according to four types of management: (1) sightseeing trains; (2) entertainment trains; (3) railway museums; and (4) local railways [46]. For example, Montenvers sightseeing train is described as the first-generation ski resort as well as an outdoor museum of the "Ice Age" [47]. Developed as a tourist site in the early 20th century, it received more than 24,000 visitors per year at the beginning. Its passenger flow increased nearly ten times until the middle of the 20th century [48]. In 2018, it attracted more than 400,000 visitors. Viewing the beauty of the landscape is the primary reason given by visitors (94.2\%) [49]. Along this site, visitors can take a cog railway 
between Chamonix and the Montenvers, where they can access to experience the views of the glacier and the surrounding mountains outside of the train [50]. The Montenvers is an excellent example of tourism development and balancing between natural landscape and heritage visiting. Alternatively, all scenic railways can also be divided into six groups according to the railway gauge ( $1435 \mathrm{~mm}$ as standard width and gauges smaller than 1435 are referred to as narrow gauge) (Figure 7).

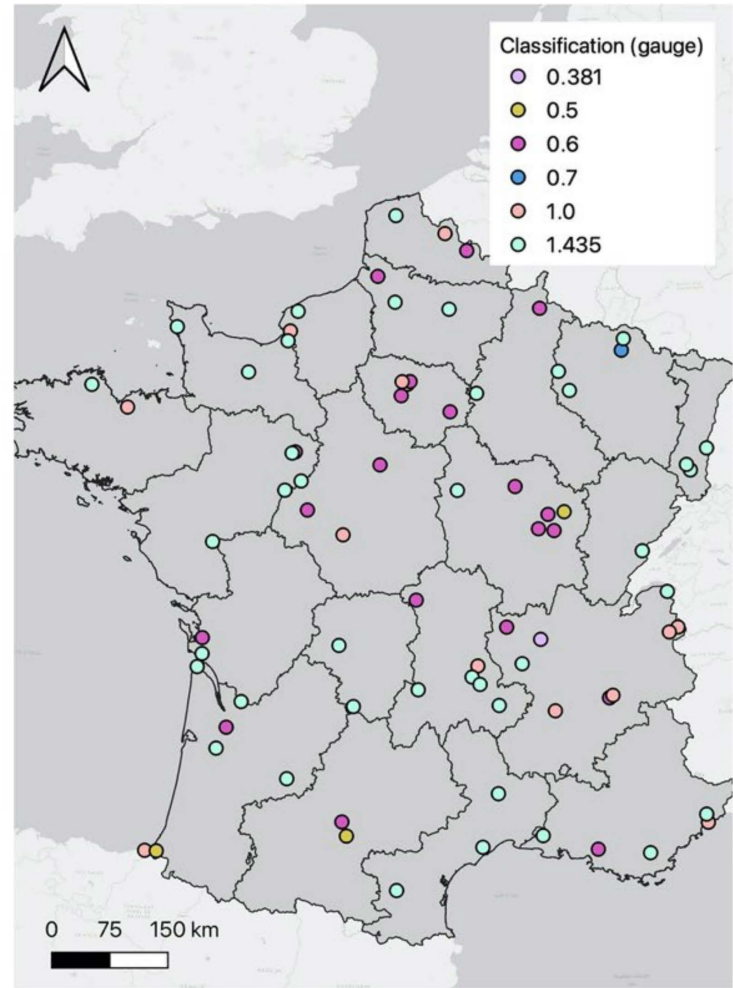

(a)

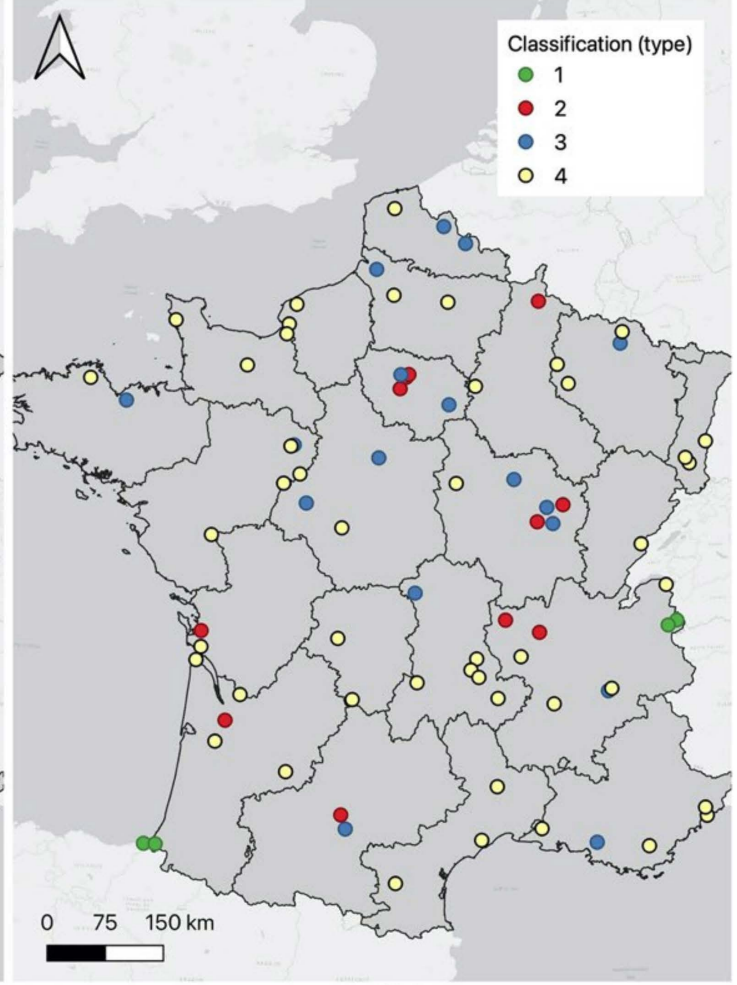

(b)

Figure 7. (a): Classification by railway types: (1) sightseeing trains; (2) entertainment trains; (3) railway museums; and (4) local railways. (b): Classification by the gauge of railways.

\section{Results}

Consequently, Table 1 summarizes the frequency of each group of scenic railways. As is seen, local railways account for the highest percentage (59.3\%), with a total length of $1172.7 \mathrm{~km}$. The number of sightseeing trains is then limited, which account for only $6.2 \%$ with a length of $61 \mathrm{~km}$. As for the railway gauge, standard railways $(1435 \mathrm{~mm})$ occupy a privileged position, which are in all 42 railways $(51.9 \%, 1022.3 \mathrm{~km})$ spreading from north to south, and the 700 and $381 \mathrm{~mm}$ railways are only each recorded in one railway. For their distribution in each region, Table 2 reveals that Rhône-Alpes owns 10 scenic railways, ranking in first place. However, for the total railway length, the Auvergne has a sum of $209.2 \mathrm{~km}$ of scenic railway, followed by the Rhône-Alpes with a length of $137.8 \mathrm{~km}$. After calculating the ratio of length and region area, it is shown that the Auvergne has a density of $7.99 \mathrm{~m} / \mathrm{km}^{2}$, ranking in first place, followed by the region of lower Normandy, and the region of Midi-Pyrénées has a value of only $0.11 \mathrm{~m} / \mathrm{km}^{2}$.

After statistical analysis, the data are published online for sharing with others. In this process, the tool "Gis2web" in QGIS is utilized, which is designed with various functionalities, for example, for extracting geo-information from database to the Internet, transferring data from GIS server to a Gis2web server, converting data to web format, and displaying information on the webpage based upon the requests of users [51]. The output data by Gis2web contain a complete set of hypertext markup language (HTML), cascading style sheets (CSS), and JavaScript (JS). As a result, the data of scenic railway along with 
French regions and an Esri base map are outputted to a webpage as shown in Figure 8. The webpage is composed of four sections, including the map tool (measurement, location, zoom in and out), base map section, legend, and the layers of data. When clicking on the data, their detailed information will be presented. The photo of railway sites is also attached to every point of scenic railway to show its landscape and railway heritage. An example of Montenvers sightseeing train is included on the page. The website is still under construction and, after collecting data covering every scenic railway, will be open and published online for the public.

Table 1. Statistics of the railway classification.

\begin{tabular}{|c|c|c|c|c|c|c|c|}
\hline Type & Frequency & Percent & Sum (km) & Gauge & Frequency & Percent & Sum (km) \\
\hline 1 & 5 & $6.2 \%$ & 61.0 & 0.381 & 1 & $1.2 \%$ & 2.5 \\
\hline 2 & 11 & $13.6 \%$ & 33.8 & 0.5 & 4 & $4.9 \%$ & 15.7 \\
\hline 3 & 17 & $21 \%$ & 58.9 & 0.6 & 20 & $24.7 \%$ & 3.6 \\
\hline \multirow[t]{3}{*}{4} & 48 & $59.3 \%$ & 1172.7 & 0.7 & 1 & $1.2 \%$ & 6.0 \\
\hline & & & & 1.0 & 13 & $16 \%$ & 207.1 \\
\hline & & & & 1.435 & 42 & $51.9 \%$ & 1022.3 \\
\hline
\end{tabular}

Table 2. Statistics of the regional distribution.

\begin{tabular}{|c|c|c|c|c|}
\hline Regions & Count & Sum (km) & $\operatorname{Mean}(\mathbf{k m})$ & $\begin{array}{l}\text { Density } \\
\left(\mathrm{m} / \mathrm{km}^{2}\right)\end{array}$ \\
\hline Rhône-Alpes & 10 & 137.80 & 13.78 & 1.80 \\
\hline Aquitaine & 7 & 53.20 & 7.60 & 1.27 \\
\hline Auvergne & 6 & 209.20 & 34.87 & 7.99 \\
\hline Burgundy & 6 & 50.50 & 8.43 & 1.59 \\
\hline Pays de la Loire & 5 & 80 & 16 & 2.47 \\
\hline Île-de-France & 5 & 13.60 & 2.72 & 1.13 \\
\hline Provence-Alpes-Côte d'Azur & 5 & 74.50 & 14.90 & 2.33 \\
\hline Lorraine & 4 & 86.80 & 21.70 & 3.66 \\
\hline Centre-Val de Loire & 4 & 53.50 & 13.375 & 1.35 \\
\hline Nord-Pas-de-Calais & 3 & 22.50 & 7.50 & 1.81 \\
\hline Picardy & 3 & 39 & 13 & 1.99 \\
\hline Lower Normandy & 3 & 97 & 32.33 & 5.44 \\
\hline Champagne-Ardenne & 3 & 58.10 & 19.37 & 2.25 \\
\hline Alsace & 3 & 30.60 & 10.20 & 3.67 \\
\hline Languedoc-Roussillon & 3 & 105.20 & 35.07 & 3.80 \\
\hline Upper Normandy & 2 & 32 & 16 & 2.59 \\
\hline Brittany & 2 & 17.90 & 8.95 & 0.65 \\
\hline Poitou-Charentes & 2 & 28 & 14 & 1.08 \\
\hline Midi-Pyrénées & 2 & 5 & 2.50 & 0.11 \\
\hline Limousin & 2 & 124 & 62 & 7.27 \\
\hline Franche-Comté & 1 & 7.50 & 7.50 & 0.46 \\
\hline
\end{tabular}




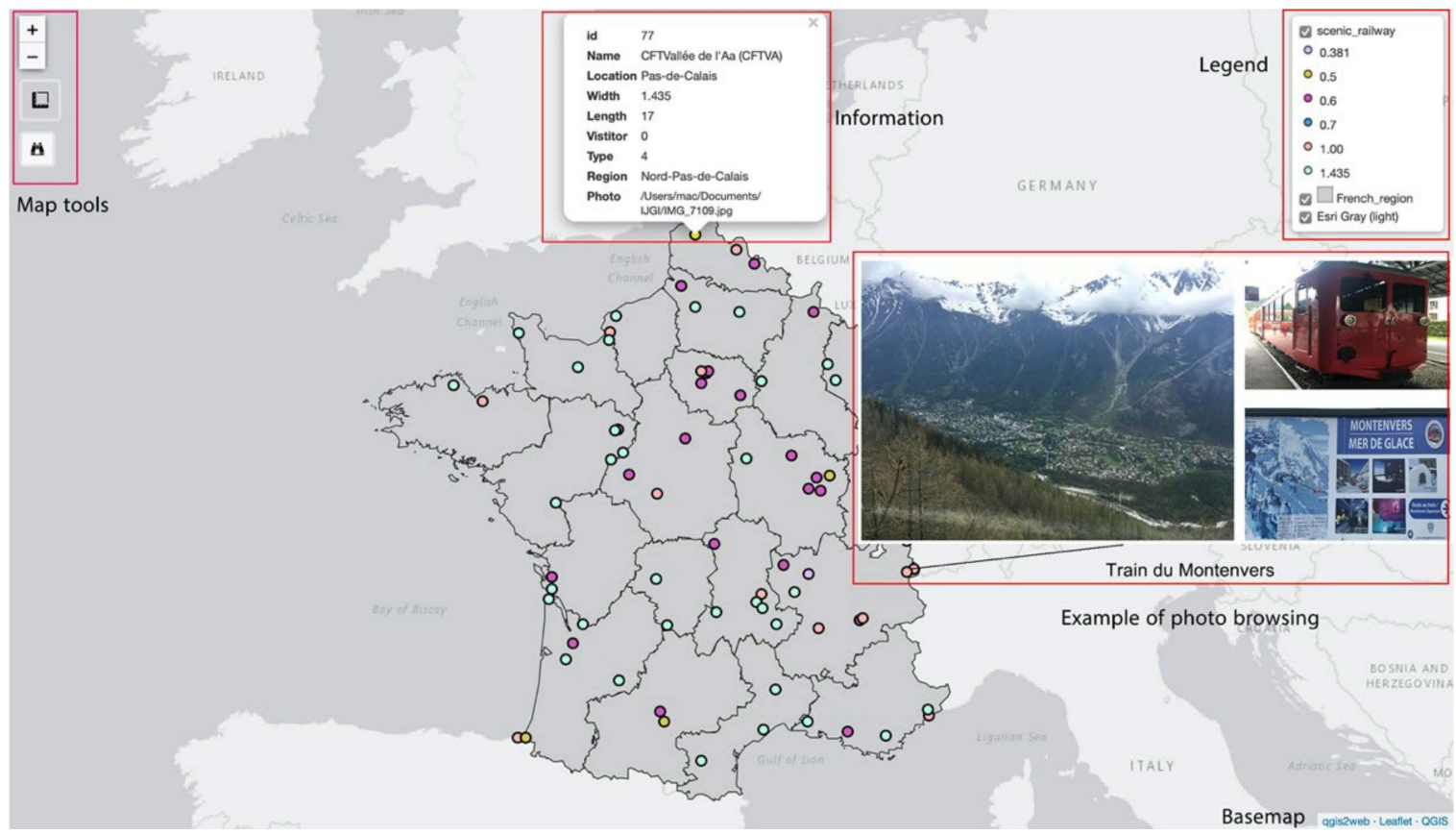

Figure 8. The output webpage of the scenic railway.

\section{Discussion}

Using GIS methodology, the results of this paper include the mapping of all 81 scenic railways in France, the map of distribution of scenic railways in comparison with other normal railways, the classification of scenic railways by railway gauge and landscape character, and a statistical analysis of the classified scenic railways. Île-de-France, Centre Val de Loire, Auvergne, and Rhône-Alpes are the regions with the highest density of scenic railways. Nord-Pas-de-Calais, Upper Normandy, Île-de-France, and Alsace are the regions with the highest railway density. Furthermore, the local railways account for the largest percentage of all railways. The number of sightseeing trains is limited. As for the railway gauge, the standard railways occupy a privileged position, but there are only one each of the 700 and $381 \mathrm{~mm}$ railways. Finally, the scenic railway data were also outputted as a webpage, showing the detailed information of every scenic railway as well as photos of these sites.

As is seen, the development of scenic railways is an effective measure to renew and revitalize railway heritage, and enhance the competitiveness of railway tourism, and is also a powerful means by which to promote the redevelopment of the local economy. Obviously, there is more than one mode of railway heritage renewal. Building a railway museum is also an important means of promoting public awareness and understanding of this type of modern industrial heritage. The scenic railway covers the railway heritage and tourist trains and pays more attention to the management of a large-scale landscape and environment behind the railway heritage and the landscape experience it brings to its visitors. For example, regarding the Montenvers sightseeing train mentioned above, the special mountaineering railway is a highlight of the scenic spots and, at the same time, its rich and diverse natural scenery resources and complete supporting facilities also attract more tourists to experience this trip. While paying attention to railways, the construction of related cultural facilities and an integration of landscape and tourism research should be of greater concern. Methods for evaluating the economic benefits, social value, and cultural significance of scenic railways should also be further discussed. In particular, analysis of the historical railway situation can be used as an indicator for further tourism and social-economic development. For example, it is used in the system for measuring the satisfaction of railway heritage tourism and modeling the relationship between railway and tourism economy [52]. 
More importantly, developing countries, where the situation of historical railways is not very optimistic, such as the old railways in India, Vietnam, etc., can learn from the experiences of scenic railway in France [53]. Taking China as an example, the management of Chinese railway heritage is still chaotic. There are several kilometers of transnational railway lines, short transportation lines located in industrial areas, and many single railway bridges and railway stations that are waiting for protection and development [54]. Learning from the experience of the scenic railway can bring a better understanding and management of these heritage sites and further stimulate the classification, registration, and evaluation of the corresponding railway relics in China. Meanwhile, many types of railways have not yet received enough attention in China. In particular, this concerns whether the earlier developed tourist trains and other small trains for leisure and entertainment in some parks can be included in the scope of scenic railway for further study.

Regarding the shortcomings in this research, the volume of visitors was collected from former research. However, the touristic flow of the scenic railways in recent years was not included in the dataset. With these data, the popularity of every scenic railway can be analyzed within the classified groups and to indicate the difference among different groups. Further research should also focus more on the four groups of sightseeing trains, entertainment trains, railway museums, and local railways to discuss their different development strategies and provide enlightenment for other countries. Moreover, the localization of scenic railways is based on maps from previous research. These railways are also searchable on Google Maps. Thus, using an application programming interface (API) to improve the accuracy of data for scenic railways can be further discussed. Other API data, such as tourism services and other natural and cultural touristic sites around scenic railways, can be also collected from the online maps, which will better serve in the touristic planning and landscape evaluation of these railway sites [55,56].

\section{Conclusions}

In conclusion, railway is of both technological, historical, and cultural values, but there are currently a large number of abandoned and neglected historical railways in both urban and suburban areas. Scenic railway has combined the meaning of landscape, heritage, and tourism used for leisure, entertainment, sightseeing, and heritage experience, mainly for the purpose of tourism rather than transportation, and these railways mainly originated for the reasons of exploring nature and protecting railway heritage. They have continuously provided huge economic and social benefits in France. Thus, introducing GIS for studying scenic railways is significant for their protection and redevelopment and is also intended for use in determining the railway density of each region and the contribution of railways to the economy and tourism. By using the GIS method, more geographic information focusing on scenic railways or historical railways can be analyzed, beyond only showing their distribution, classification, and touristic situation. This paper shows an example of the GIS process covering georeferencing, remapping, data relating and joining, density calculating, classifying, and outputting data online. Based on the research results, further tourism planning and heritage redevelopment can be carried out, especially through the use of interactive maps serving for railway tourism, which can provide an interesting storytelling narrative for tourists.

In future work, more spatial technologies will be involved in the research of scenic railways, for example, using TLS to record the landscape of railways and monitor heritage changes, and introducing the BIM to create the model of heritages sites that serve for the future tourism activities and heritage analysis. The volunteered geographic information (VGI) and georeferenced crowdsourcing are also helpful to keep the data updated and to improve public participation in heritage observation. The participants who are interested in sharing their photos of scenic railways with others can upload their geotagged photos to an online platform, such as a specially designed mobile app for scenic railways. In this way, the data uploaded by the tourists that have visited scenic railways, as a method of VGI, will benefit future scientific research. For example, current tourism activities have been 
influenced by the COVID-19 situation. Applying VGI and crowdsourcing for studying scenic railway is of importance. After creating an app, online information volunteered by participants can be gathered from their shared photos and experiences of scenic railways. A large amount of spatial data can be collected quickly and effectively, and scholars can use and analyze these data for efficient landscape evaluation without going to the sites themselves.

Author Contributions: Conceptualization, Guiye Lin and Kun Sang; Formal analysis, Guiye Lin and Kun Sang; Funding acquisition, Guiye Lin; Investigation, Guiye Lin, Luoning Xiang and Kun Sang; Methodology, Guiye Lin, Luoning Xiang and Kun Sang; Software, Guiye Lin and Kun Sang; Supervision, Guiye Lin and Kun Sang; Writing — review \& editing, Guiye Lin and Kun Sang. All authors have read and agreed to the published version of the manuscript.

Funding: This paper is funded by China Scholarship Council (CSC), Grant Number: 201708440230; and Xiamen University Malaysia Research Fund, Grant Number: XMUMRF/2022-C9/IART/0013.

Institutional Review Board Statement: Not applicable.

Informed Consent Statement: Not applicable.

Data Availability Statement: The French shapefile data are collected from DIVA-GIS: www.divagis.org (accessed on 16 September 2021). The scenic railway data are collected from UNECTO: http:/ / www.unecto.fr/en (accessed on 10 September2021).

Conflicts of Interest: The authors declare no conflict of interest.

\section{References}

1. Romanova, E.; Vinogradova, O.; Kretinin, G.; Drobiz, M. The effect of railway network evolution on the Kaliningrad region's landscape environment. Balt. Reg. 2015, 4, 137-148. [CrossRef]

2. Coulls, A. Railways as World Heritage Sites. Occasional Papers for the World Heritage Convention. 1999. Available online: https:/ / www.icomos.org/studies/railways.pdf (accessed on 16 September 2021).

3. Yang, L. Research on the Status Quo and Protection Countermeasures of Chinese Railway Cultural Heritage. Chin. Cult. Reg. Sci. Res. 2011, 3, 54-57.

4. Zhang, D. Research on World Railway Heritage and Its Enlightenment to the Protection of my country's Railway Heritage. J. Zhengzhou Univ. Li Indu 2012, 13, 44-49.

5. Burman, P.; Stratton, M. Conserving the Railway Heritage; Taylor \& Francis: York, UK, 1997.

6. FEDECRAIL. The Riga Charter. In Proceedings of the Annual Meeting of FEDECRAIL, Riga, Latvia, 16 April 2005.

7. Guillaume, S. L'évolution de l'inventaire du patrimoine ferroviaire immobilier en France, des années 1970 à nos jours. Rev. D'histoire Chemins 2009, 40, 155-168.

8. Batisse, F. Restructuring of Railways in France: A pending process. Jpn. Railw. Transp. Rev. 2003, 34, 32-41.

9. SNCF. Memento Statistiques SNCF Mobilités 2017. La Plaine Saint-Denis, France: SNCF Mobilités. 2017. Available online: http://medias.sncf.com/sncfcom/open-data/pdf/MEMENTO_STATISTIQUES_2017.pdf (accessed on 16 September 2021).

10. Autorité de Régulation des Activités Ferroviaires et Routières (ARAFR). Observatory of Transport and Mobility: The French Passenger Rail Transport Market 2018. 2019. Available online: https:/ / www.arafer.fr/observatoire-des-transports / (accessed on 16 September 2021).

11. Ma, S. Discovery of Landscape: Modern Railway Travel Trend and National Construction (1923-1937). Ph.D. Thesis, Nanjing University, Nanjing, China, 2013.

12. Pacey, P. The picturesque railway. Vis. Resour. 2002, 18, 285-309. [CrossRef]

13. Baker, J.C. Mobility, tropicality and landscape: The Darjeeling Himalayan Railway, 1881-1939. J. Hist. Geogr. 2014, 44, 133-144. [CrossRef]

14. UNESCO. Rhaetian Railway in the Albula/Bernina Landscapes. 2008. Available online: https://whc.unesco.org/en/list/1276 /documents / (accessed on 14 September 2021).

15. De Block, G. Planning Rural-Urban Landscapes: Railways and Countryside Urbanisation in South-West Flanders, Belgium (1830-1930). Landsc. Res. 2014, 39, 542-565. [CrossRef]

16. Fan, Y. Space, Landscape, and Memory: Chengdu's Shaocheng Park and the Historical Memory of the Railway Protection Movement. Chin. Stud. Hist. 2014, 47, 6-28.

17. Orbaşli, A.; Woodward, S. A railway 'route'as a linear heritage attraction: The Hijaz Railway in the Kingdom of Saudi Arabia. J. Herit. Tour. 2008, 3, 159-175. [CrossRef]

18. Auphan, E. Qu'est-ce que le paysage ferroviaire? Défrichement d'un concept. Rev. D'histoire Chemins 2005, 32, 19-41. [CrossRef]

19. Marchi, J.J. Les chemins de fer touristiques: Des petits trains singuliers et pluriels. Rev. D'histoire Chemins 2008, 38, 190-212. [CrossRef] 
20. Little, C.E. Greenways for America; JHU Press: Baltimore, MD, USA, 1995.

21. Zhao, H.; Wang, D.; Wei, Q. Review and prospects of greenway research progress at home and abroad. Planner 2016, 3, 135-141.

22. Guccio, C.; Martorana, M.F.; Mazza, I.; Rizzo, I. Technology and public access to cultural heritage: The Italian experience on ICT for public historical archives. In Cultural Heritage in a Changing World; Springer: Cham, Switzerland, 2016; pp. 55-75.

23. Ferreira Lopes, P. Achieving the state of research pertaining to GIS applications for cultural heritage by a systematic literature review. Int. Arch. Photogramm. Remote Sens. Spat. Inf. Sci. 2018, 42, 169-175. [CrossRef]

24. Goodchild, M.F. Twenty years of progress: GIScience in 2010. J. Spat. Inf. Sci. 2010, 1, 3-20. [CrossRef]

25. Fischer, P.F.; Farrelly, C.; Maddocks, A.; Ruggles, C.L.N. Spatial analysis of visible areas from the Bronze Age cairns of Mull. J. Archaeol. Sci. 1997, 24, 581-592. [CrossRef]

26. Box, P. Geographic Information Systems and Cultural Resource Management: A Manual for Heritage Site Managers. Bangkok: UNESCO Principal Regional Office for Asia and the Pacific. 1999. Available online: https://bangkok.unesco.org/content/gisand-cultural-resource-management-manual-heritage-managers (accessed on 16 September 2021).

27. Sánchez-Aparicio, L.J.; Masciotta, M.-G.; García-Alvarez, J.; Ramos, L.F.; Oliveira, D.V.; Martín-Jiménez, J.A.; González-Aguilera, D.; Monteiro, P. Web-GIS approach to preventive conservation of heritage buildings. Autom. Constr. 2020, 118, 103304. [CrossRef]

28. Siebert, L. Using GIS to map rail network history. J. Transp. Hist. 2004, 25, 84-104. [CrossRef]

29. Gregory, I.N.; Schwartz, R.M. National Historical Geographical Information System as a tool for historical research: Population and railways in Wales, 1841-1911. Int. J. Humanit. Arts Comput. 2009, 3, 143-161. [CrossRef]

30. Martí-Henneberg, J. European integration and national models for railway networks (1840-2010). J. Transp. Geogr. 2013, 26, 126-138. [CrossRef]

31. Atack, J.; Bateman, F.; Haines, M.; Margo, R.A. Did Railroads Induce or Follow Economic Growth? Urbanization and Population Growth in the American Midwest, 1850-1860. Soc. Sci. Hist. 2010, 34, 171-197. [CrossRef]

32. Stanev, K. A historical GIS approach to studying the evolution of the railway and urban networks: The Balkans, 1870-2001. Hist. Methods A J. Quant. Interdiscip. Hist. 2013, 46, 192-201. [CrossRef]

33. Morillas-Torné, M. Creation of a Geo-Spatial Database to Analyse Railways in Europe (1830-2010). A Historical GIS Approach. J. Geogr. Inf. Syst. 2012, 4, 176-187. [CrossRef]

34. Thevenin, T.; Schwartz, R.; Sapet, L. Mapping the distortions in time and space: The French railway network 1830-1930. Hist. Methods A J. Quant. Interdiscip. Hist. 2013, 46, 134-143. [CrossRef]

35. Thevenin, T.; Mimeur, C.; Schwartz, R.; Sapet, L. Measuring one century of railway accessibility and population change in France. A historical GIS approach. J. Transp. Geogr. 2016, 56, 62-76. [CrossRef]

36. Poplin, A. Exploring Evocative Places and their Characteristics. Cartogr. J. 2020, 57, 130-146. [CrossRef]

37. Edler, D. Where Spatial Visualization Meets Landscape Research and "Pinballology": Examples of Landscape Construction in Pinball Games. KN-J. Cartogr. Geogr. Inf. 2020, 70, 55-69. [CrossRef]

38. Wolff, J.P. La gouvernance des chemins de fer touristique. Rev. Géograph Pyrénées Sud-Ouest 2017, 43, 53-67. [CrossRef]

39. UNECTO. List of French Historical Railways. 2020. Available online: http:/ / www.unecto.fr/en (accessed on 16 September 2021).

40. Dann, G.M. Travel by train: Keeping nostalgia on track. In Tourism: The State of the Art; John Wiley \& Sons: Chichester, UK, 1994; pp. 775-782.

41. Prideaux, B. Tracks to tourism: Queensland rail joins the tourist industry. Int. J. Tour. Res. 1999, 1, 73-86. [CrossRef]

42. Zohar, M. A city hit by an earthquake: An HGIS approach to reconstructing the damage in Tiberias (Israel) in 1837. Int. J. Geogr. Inf. Sci. 2017, 31, 81-99. [CrossRef]

43. Blancheton, B.; Marchi, J.J. Le développement du tourisme ferroviaire en France depuis 1870. Hist. Économie Société 2011, 30, 95-113. [CrossRef]

44. Velasco, G. The post, the railroad and the state: An HGIS approach to study Western Canada settlement, 1850-1900. In The Routledge Companion to Spatial History; Routledge: London, UK, 2018; pp. 375-393.

45. Lafreniere, D.; Weidner, L.; Trepal, D.; Scarlett, S.F.; Arnold, J.; Pastel, R.; Williams, R. Public participatory historical GIS. Hist. Methods A J. Quant. Interdiscip. Hist. 2019, 52, 132-149. [CrossRef]

46. Blancheton, B.; Marchi, J.-J. The three systems of rail tourism: French case. Tour. Manag. Perspect. 2013, 5, 31-40. [CrossRef]

47. Delorme, F. Du village-station à la station-village. Un siècle d'urbanisme en montagne. Rev. Patrim. 2014, 24, 1-19. [CrossRef]

48. Debarbieux, B. Chamonix-Mont-Blanc: Les Coulisses de L'amenagement Chamonix-Mont-Blanc: Behind the Scenes of the Development; Presses Universitaires de Grenoble: Grenoble, France, 1990.

49. Salim, E.; Ravanel, L. Last chance to see the ice: Visitor motivation at Montenvers-Mer-de-Glace, French Alps. Tour. Geogr. 2020, 22, 2-14. [CrossRef]

50. Wildi, W. Mer de Glace (Chamonix-Mont Blanc): From Little Ice age to Modern Times. Field Guide; Institut F.A. Forel, Université de Genève: Geneva, Switzerland, 2014; pp. 1-14. Available online: https://archive-ouverte.unige.ch/unige:40252 (accessed on 16 September 2021).

51. Meng, X.; Fowler, R.; Rieken, E. Bridging the Gap Between GIS and the WWW. In Proceedings of the 6th International World Wide Web Conference, Santa Clara, CA, USA, 7-11 April 1997.

52. Li, X.; Guo, L. Investigation of a coupling model of coordination between Xinjiang High-speed Railway and the Tourism Economy. In Proceedings of the 7th International Conference on Green Materials and Environmental Engineering, Changsha, China, 23 April 2021; EDP Sciences: Les Ulis, France, 2021. 
53. Prasad, R. Railways in Colonial South Asia. Mobil. Hist. 2015, 6, 120-126. [CrossRef]

54. Cano-Sanchiz, J.M.; Zhang, R.; Lei, L. The Image of Railways in China: Museums, Technology and Narratives of Progress. Hist. Environ. Policy Pract. 2020, 11, 258-281. [CrossRef]

55. Niu, Q.; Dong, Z. Public Participation in Urban Planning Based on New Mobile Social Platform. Management 2017, 9 , 46-51.

56. Aksoy, C.; Bayar, Z. Archaeological Ethnography of the Battle of Aslihanlar (29-30 August 1922): A Case Study of Public Archaeology, Visual Storytelling, and Interactive Map Design. Eur. J. Archaeol. 2016, 19, 68-94. [CrossRef] 